\title{
PENGEMBANGAN INSTRUMEN PENDETEKSI MISKONSEPSI KESETIMBANGAN KIMIA PADA PESERTA DIDIK SMA
}

\author{
Das Salirawati \\ Jurusan Pendidikan Kimia FMIPA UNY \\ Jl. Colombo No.1 Yogyakarta 55281 \\ das.salirawati@yahoo.co.id
}

\begin{abstract}
Abstrak
Tujuan penelitian ini adalah mengembangkan dan menghasilkan produk berupa Instrumen Pendeteksi Miskonsepsi Kesetimbangan Kimia (IPMKK) pada peserta didik kelas XI SMA dengan uji kualitas IPMKKK berdasarkan expert judgment melalui Forum Group Discussion (FGD) dilanjutkan analisis Teori Respons Butir (TRB) tiga parameter dan uji fisibilitas penggunaan IPMKK. Penelitian ini merupakan penelitian pengembangan dengan model prosedural mengadaptasi prosedur pengembangan Borg \& Gall. Hasil analisis kebutuhan (need assessment) dan kaji pustaka dipilih materi pokok kesetimbangan kimia dan instrumen berbentuk tes pilihan ganda dengan alasan setengahterbuka. Simpulan hasil penelitian ini adalah telah berhasil dikembangkan IPMKK pada peserta didik kelas XI SMA. Hasil uji fisibilitas menunjukkan bahwa guru-guru kimia SMA tidak mengalami kesulitan dalam menerapkan IPMKK dan dapat mengikuti cara menganalisis data dengan mudah. IPMKK yang diterapkan di lapangan dapat mendeteksi terjadinya miskonsepsi kimia, yaitu miskonsepsi tipe Mi-1 sebesar 13,84\% dan tipe Mi2 sebesar 18,43\% untuk tingkat Provinsi DIY.
\end{abstract}

Kata kunci: pengembangan instrumen, miskonsepsi, kesetimbangan kimia 


\title{
DEVELOPMENT OF A DETECTING INSTRUMENT CHEMICAL EQUILIBRIUM MISCONCEPTION OF SENIOR HIGH SCHOOL STUDENTS
}

\author{
Das Salirawati \\ Jurusan Pendidikan Kimia FMIPA UNY \\ Jl. Colombo No.1 Yogyakarta 55281 \\ das.salirawati@yahoo.co.id
}

\begin{abstract}
This research is aimed at developing a product in the form of a Chemical Equilibrium Misconception Detecting Instrument or IPMKK for Grade XI senior high school students to investigate the quality of IPMKK based on the expert judgment using the Focus Group Discussion (FGD), continued with an analysis using the three-parameter Item Response Theory (IRT) and the feasibility of IPMKK implementation in the field. This research was a research and development study using the procedural model, adapted from Borg \& Gall model. The development of the product began by conducting the needs assessment and the literature review to choose a chemical equilibrium and multiple choice test with half-open reason as the instrument to be developed. Findings suggest that this research succeeds in developing a Chemical Equilibrium Misconception Detecting Instrument (IPMKK) for Grade XI senior high school students. The feasibility test suggests that Senior High School chemistry teachers do not have difficulty in implementing the instrument and can conduct the data analysis easily. The implementation of the instrument in the DIY province detected that there was M1i-1 chemistry misconception by $13.84 \%$ Mi-1 and Mi-2 by $18.43 \%$.
\end{abstract}

Keywords: instrument development, misconception, chemical equilibrium 


\section{Pendahuluan}

Memahami konsep kimia dalam pembelajaran kimia merupakan hal sangat penting. Pada kenyataannya, peserta didik sering mengalami kesulitan dalam memahami berbagai konsep kimia. Pemahaman konsep kimia oleh peserta didik yang tidak sesuai dengan konsep kimia yang benar menurut para ahli kimia, disebut sebagai miskonsepsi kimia (Suparno,2005: 4). Akibat lebih jauh terjadinya miskonsepsi kimia adalah hasil belajar kimia peserta didik yang rendah.

Studi pendahuluan yang dilakukan terhadap 125 guru-guru kimia SMA/MA di Jawa Tengah dan DIY menunjukkan materi pokok kesetimbangan kimia menempati urutan kedua sebagai materi yang sering menyebabkan miskonsepsi pada peserta didik. Selain itu, penelitian yang dilakukan oleh Sutiman, Salirawati, \& Permanasari (2003) terhadap 236 peserta didik di Kabupaten Sleman menunjukkan 63,42\% dari jumlah sampel mengalami miskonsepsi pada materi pokok kesetimbangan kimia dan menempati urutan pertama dari seluruh materi pokok kimia yang ada di SMA. Penelitian ini dilakukan dengan menggunakan instrumen tes pilihan ganda 5 alternatif jawaban dengan alasan tertutup seperti yang dikembangkan oleh Treagust (1987: 519).

Penelitian miskonsepsi kimia selama ini masih jarang dilakukan. Dominasi penelitian pendidikan kimia, khususnya miskonsepsi kimia terjadi sejak 15 tahun terakhir yang dipicu oleh kenyataan bahwa kimia berisi konsep kimia yang cenderung bersifat abstrak (Gabel, 1999: 550). Hal ini berbeda dengan penelitian bidang pendidikan fisika dan biologi yang telah banyak mengkaji miskonsepsi sejak tahun 1980-an (Nakhleh, 1992: 191).

Instrumen untuk mendeteksi adanya miskonsepsi kimia, khususnya tentang materi pokok kesetimbangan kimia belum banyak dijumpai dan dikembangkan. Kalaupun ada, sebagian besar berbentuk soal pilihan ganda biasa, soal uraian, atau wawancara. Selain sulit diperoleh dari pengembang instrumen tersebut, kurikulum, kedalaman dan keluasan materi kesetimbangan kimia di negara lain berbeda, sehingga relatif tidak sesuai jika diterapkan di Indonesia. Oleh karena itu, sangat penting dilakukan pengembangan instrumen pendeteksi miskonsepsi kimia, sehingga dapat 
digunakan secara mudah oleh guru dalam mendeteksi adanya miskonsepsi pada peserta didik SMA di Indonesia. Meskipun miskonsepsi sulit dibetulkan, tetapi jika dapat dideteksi secara dini, maka dapat dilakukan pencegahan sesegera mungkin (Berg, 1991: 17). Terkait dengan hal tersebut, penelitian ini bertujuan untuk mengembangkan dan menghasilkan produk berupa Instrumen Pendeteksi Miskonsepsi Kesetimbangan Kimia (IPMKK) pada peserta didik kelas XI SMA dengan uji kualitas IPMKKK berdasarkan expert judgment melalui Forum Group Discussion (FGD) dilanjutkan analisis Teori Respons Butir (TRB) tiga parameter dan uji fisibilitas penggunaan IPMKK.

Penelitian ini mengadaptasi dengan cara menggabungkan dua instrumen yang telah dikembangkan, yaitu tes pilihan ganda dengan alasan terbuka (Amir, Frankl, \& Tamir, 1987: 20, Krishnan \& Howe, 1994: 654) dan tes pilihan ganda dengan alasan tertentu (Treagust, 1987: 519). Dengan mempertimbangkan kelemahan kedua instrumen tersebut, maka dalam penelitian ini akan dikembangkan Instrumen Pendeteksi Miskonsepsi Kimia (IPMKK) berbentuk tes pilihan ganda dengan alasan setengahterbuka. Bentuk ini dipilih mengingat instrumen tes pilihan ganda dengan alasan terbuka memiliki kelemahan adanya peserta didik yang tidak mengisi alasan dengan berbagai sebab. Demikian juga instrumen tes pilihan ganda dengan alasan tertentu memiliki kelemahan terbatasinya kebebasan mengungkapkan alasan di luar yang tersedia dan kemungkinan pilihan alasan yang hanya spekulatif.

\section{Metode Penelitian}

Penelitian ini merupakan penelitian pengembangan dengan model prosedural untuk menghasilkan produk berupa Instrumen Pendeteksi Miskonsepsi Kesetimbangan Kimia (IPMKK) bagi peserta didik SMA kelas XI. Model mengadaptasi prosedur pengembangan Borg \& Gall (1983) menjadi 5 langkah, yaitu: (1) analisis produk yang akan dikembangkan; (2) pengembangan produk awal; (3) validasi produk; (4) uji coba lapangan; dan (5) revisi produk. Produk yang berupa IPMKK kemudian diteliti kualitasnya berdasarkan (1) penilaian para ahli melalui expert judgment dengan 
menggunakan teknik FGD; (2) analisis menggunakan Teori Respons Butir (TRB) atau Item Response Theory (IRT) dengan tiga parameter; dan (3) fisibilitas penggunaannya di lapangan.

Model produk dalam penelitian pengembangan ini berupa Instrumen Pendeteksi Miskonsepsi Kesetimbangan Kimia (IPMKK) yang berbentuk tes pilihan ganda 5 alternatif jawaban dengan alasan setengah-terbuka, artinya peserta didik setelah memilih alternatif jawaban yang disediakan, diwajibkan memilih alasan yang telah tersedia dan/atau menuliskan/menambahkan alasan dia memilih alternatif jawaban tersebut. Bentuk instrumen yang dipilih merupakan adaptasi dengan cara menggabungkan dua bentuk instrumen yang masing-masing dikembangkan oleh Amir, Frankl, \& Tamir (1987: 20) dan Treagust (1987: 519) dengan tujuan agar kelemahan kedua instrumen dapat diatasi.

Dalam rangka melakukan validasi isi terhadap IPMKK yang dikembangkan ditempuh melalui expert judgment menggunakan teknik FGD dengan melibatkan ahli bidang ilmu kimia, pendidikan kimia, miskonsepsi, dan psikometri yang dipilih dari beberapa Perguruan Tinggi berdasarkan keahliannya. Untuk keperluan FGD disusun instrumen berupa lembar masukan untuk diisi oleh seluruh expert peserta FGD. Angket isian terdiri dari kolom tentang hal yang dikritisi dan masukan yang diberikan dari hal yang dikritisi tersebut. Masukan expert diharapkan berkaitan dengan bidang keahliannya, sehingga benar-benar berguna untuk perbaikan dan penyempurnaan instrumen yang dikembangkan.

FGD juga melibatkan para praktisi di lapangan sebagai reviewer, yaitu dosen Pendidikan Kimia dan guru kimia SMA. Instrumen untuk reviewer berupa angket isian tentang kualitas soal ditinjau dari aspek materi, konstruksi, dan bahasa yang mengacu pada ketentuan Ditjen Dikti (2008). Semua masukan, baik dari expert maupun reviewer digunakan sebagai dasar untuk merevisi produk awal IPMKK yang dikembangkan.

Instrumen yang disusun untuk keperluan validasi empiris berupa seperangkat tes berjumlah 30 butir tes, yang merupakan Produk I IPMKK yang telah direvisi berdasarkan masukan expert dan reviewer pada FGD dan disebut Produk II IPMKK. Produk II IPMKK adalah IPMKK yang telah memenuhi validitas isi (valid secara teoretis). 
Produk III IPMKK selanjutnya digunakan untuk uji fisibilitas yang hasilnya berupa data pola jawaban peserta didik terhadap setiap butir tes dalam IPMKK. Uji fisibilitas juga bertujuan untuk mengetahui mudah sukarnya IPMKK diterapkan di lapangan.

Uji fisibilitas juga menghasilkan data berupa kategori tingkat pemahaman peserta didik, yaitu memahami, miskonsepsi, memahami sebagian tanpa miskonsepsi, dan tidak memahami dengan ketentuan kategori sebagai berikut:

Tabel 1. Kemungkinan Pola Jawaban Peserta Didik dan Kategorinya

\begin{tabular}{cll}
\hline No & \multicolumn{1}{c}{ Pola Jawaban Peserta Didik } & \multicolumn{1}{c}{$\begin{array}{c}\text { Kategori Tingkat } \\
\text { Pemahaman }\end{array}$} \\
\hline 1. Jawaban inti tes benar - alasan benar & memahami (M) \\
2. Jawaban inti tes benar - alasan salah & miskonsepsi (Mi-1) \\
3. Jawaban inti tes salah - alasan benar & miskonsepsi (Mi-2) \\
4. Jawaban inti tes salah - alasan salah & tidak memahami (TM-1) \\
5. Jawaban inti tes salah - alasan tidak diisi & tidak memahami (TM-2) \\
6. Jawaban inti tes benar - alasan tidak diisi & memahami sebagian \\
& & tanpa miskonsepsi (MS-1) \\
7. & Tidak menjawab inti tes dan alasan & tidak memahami (TM-3) \\
\hline
\end{tabular}

Kategori tersebut dirumuskan dengan mengadaptasi kategori yang dilakukan dalam penelitian miskonsepsi Abraham (1992: 113). Berdasarkan kategori tersebut dapat ditentukan pada butir-butir tes mana peserta didik mengalami miskonsepsi dan seberapa besar (persentase) peserta didik yang mengalami miskonsepsi. Dengan melihat persentase tiap butir tersebut, maka dapat diketahui uraian materi pokok kesetimbangan kimia mana yang menunjukkan rerata persentase terbesar pada kategori miskonsepsi, baik miskonsepsi tipe Mi-1 maupun tipe Mi-2.

Penelitian pengembangan produk ini berujung pada dihasilkannya Produk Akhir IPMKK lengkap dengan petunjuk penggunaan dan cara menganalisisnya. Dengan petunjuk yang jelas dan cara analisis yang diser- 
takan dalam IPMKK diharapkan guru kimia SMA dengan mudah menerapkannya sekaligus menganalisis dan menentukan terjadinya miskonsepsi pada peserta didik.

\section{Hasil Penelitian dan Pembahasan}

Hasil uji validasi oleh ahli (expert) melalui expert judgment menggunakan teknik FGD diperoleh kesepakatan bentuk Instrumen Pendeteksi Miskonsepsi Kimia (IPMKK), yaitu Tes Pilihan Ganda dengan Alasan Setengah-Terbuka (TPGAST) dan jumlah butir tes yang diterima sebanyak 30 soal, sedangkan 10 soal dihilangkan, yaitu nomor 4, 11, 16, 20, 22, 30, $31,33,39$, dan 40. Sepuluh soal yang dihilangkan sesuai dengan masukan yang diberikan oleh expert dan reviewer dan masukan guru yang menyatakan 40 soal terlalu banyak jika diujikan 2 jam pelajaran (90 menit). Masukan ini menjadi pertimbangan penting mengingat pengalaman guru di lapangan dalam mengadakan ujian bagi peserta didiknya.

Sebanyak 800 peserta didik SMA kelas XI dari 19 SMA yang ada di DIY (Negeri dan Swasta) dilibatkan dalam validasi empiris. Berdasarkan analisis dengan teori respons butir tiga parameter yang dikalibrasi menggunakan software BILOGMG untuk menentukan butir-butir tes yang fit dengan meninjau harga peluang setelah harga ketiga parameter dimasukkan dalam persamaan model logistik (Hambleton \& Swaminathan, 1985: 107). Dari 30 soal dalam Produk II IPMKK diperoleh 24 butir tes yang fit dan 6 butir tes yang tidak fit. Soal-soal yang tidak fit adalah soal yang memiliki harga $\mathrm{p}<0,05$, yaitu soal nomor $2,4,11,12,15$, dan 27 . Selanjutnya, 24 butir tes dalam IPMKK ditata dan diurutkan kembali sehingga menjadi Produk III IPMKK yang fit secara empiris.

Produk III IPMKK yang telah valid secara empiris setelah melalui analisis teori respons butir (TRB) dengan tiga parameter, yaitu sebanyak 24 soal diujicobakan ke lapangan terhadap $\pm 20 \%$ SMA yang ada di DIY. Jumlah SMA yang digunakan sebanyak 29 dari 141 SMA (Negeri dan Swasta) yang ada di DIY dengan jumlah peserta didik yang terlibat sebanyak 1002. Data pola jawaban yang dikumpulkan ditabulasi dengan 
menuliskan jawaban soal inti dan alasan agar dapat dikategorikan ke dalam tingkat pemahaman yang telah ditentukan.

\section{a. Kategori Miskonsepsi Tipe Mi-1}

Dengan mencermati hasil rekapitulasi pola jawaban peserta didik sebanyak 1002 dapat ditentukan butir tes yang memberikan kontribusi persentase terbesar pada kategori miskonsepsi tipe Mi-1 dan pola jawaban terbanyak yang diberikan peserta didik sehingga mereka dikategorikan mengalami miskonsepsi.

Tabel 2. Pola Respon Terbanyak Peserta Didik yang Mengalami Miskonsepsi Tipe Mi-1

\begin{tabular}{|c|c|c|c|c|c|c|}
\hline \multirow{2}{*}{ Tingkat } & \multicolumn{4}{|c|}{ Nomor } & \multicolumn{2}{|c|}{$\begin{array}{l}\text { Respon } \\
\text { Terbanyak }\end{array}$} \\
\hline & & & & & Pola & $\Sigma$ \\
\hline Provinsi DIY & 1002 & 22 & 412 & 42,12 & $\mathrm{E}, \mathrm{E}$ & 170 \\
\hline Kota Yogyakarta & 216 & 3 & 103 & 47,69 & $\mathrm{D}, \mathrm{A}$ & 92 \\
\hline Bantul & 179 & 22 & 79 & 44,43 & $\mathrm{E}, \mathrm{E}$ & 49 \\
\hline Sleman & 190 & 22 & 116 & 61,05 & $\mathrm{E}, \mathrm{E}$ & 44 \\
\hline Kulon Progo & 208 & 22 & 89 & 42,79 & $\mathrm{E}, \mathrm{B}$ & 39 \\
\hline Gunung Kidul & 209 & 12 & 111 & 53,11 & $\mathrm{D}, \mathrm{B}$ & 57 \\
\hline
\end{tabular}

Pada soal nomor 22 sebagian besar peserta didik yang mengalami miskonsepsi tipe Mi-1 dengan memberikan pola jawaban E - E untuk tingkat Provinsi, Kabupaten Bantul, dan Sleman. Alasan E salah karena katalis tidak dapat menggeser kesetimbangan, katalis hanya berfungsi mempercepat tercapainya kesetimbangan.

\section{b. Kategori Miskonsepsi Tipe Mi-2}

Dengan mencermati hasil rekapitulasi persentase setiap butir tes dan pola jawaban miskonsepsi dari setiap kabupaten dan provinsi dapat ditentukan butir tes yang memberikan kontribusi persentase terbesar pada kategori miskonsepsi tipe Mi-2, yaitu peserta didik yang menjawab inti tes salah tetapi alasan benar. 
Jurnal Penelitian dan Evaluasi Pendidikan

Tabel 3. Pola Respon Terbanyak Peserta Didik yang Mengalami Miskonsepsi Tipe Mi-2

\begin{tabular}{lcccccc}
\hline \multirow{2}{*}{ Tingkat } & \multirow{2}{*}{$\begin{array}{c}\text { Nomor } \\
\text { Sampel }\end{array}$} & Soal & $\Sigma$ & $\%$ & \multicolumn{2}{c}{$\begin{array}{c}\text { Respon } \\
\text { Terbanyak }\end{array}$} \\
\cline { 6 - 8 } & & & & & Pola & $\Sigma$ \\
\hline Provinsi DIY & 1002 & 15 & 459 & 45,81 & C, C & 164 \\
Kota Yogyakarta & 216 & 1 & 144 & 66,67 & E, D & 93 \\
Bantul & 179 & 1 & 119 & 66,48 & E, D & 106 \\
Sleman & 190 & 15 & 103 & 54,21 & A, C & 31 \\
Kulon Progo & 208 & 15 & 126 & 60,58 & C, C & 57 \\
Gunung Kidul & 209 & 16 & 105 & 50,24 & A, A & 61 \\
\hline
\end{tabular}

Miskonsepsi tipe Mi-2 pada tingkat provinsi terbesar dialami peserta didik pada soal nomor 15, demikian pula di Kabupaten Sleman dan Kulon Progo. Miskonsepsi dapat terjadi, jika peserta didik menganggap rumus mencari Kp sama dengan rumus mencari Kc. Kemungkinan kesalahan juga terjadi apabila peserta didik menghitung $\mathrm{Kp}$ dengan rumus $\mathrm{Kc}$ tetapi terbalik atau peserta didik tidak mencari tekanan parsial gas-gas yang terlibat terlebih dahulu melainkan mol gas-gas dalam kesetimbangan langsung dimasukkan dalam rumus.

Bagi peserta didik yang tidak memperhatikan, maka miskonsepsi dapat terjadi karena molaritas suatu zat dianggap sama dengan mol zat tersebut. Pemahaman salah berikutnya adalah anggapan bahwa volume sebanding dengan tekanan, sehingga molaritas yang seharusnya mol/volume diubah menjadi mol/tekanan. Miskonsepsi ini akan berdampak sangat besar terhadap pemahaman konsep-konsep kimia berikutnya yang banyak menggunakan konsep molaritas dalam perhitungannya.

Dalam menguasai materi kimia, kemampuan operasi matematika sangat diperlukan mengingat banyaknya konsep kimia yang memerlukan perhitungan. Hal ini sesuai dengan hasil penelitian yang dilakukan Herron \& Greenbowe (1986) yang menunjukkan 31 peserta didik di Secondary School mengalami kesulitan mengintegrasikan aljabar dalam soal-soal stiokiometri, meskipun hukum dan rumusnya dikuasai dengan baik. Penelitian lain dilakukan oleh Dierks, Weninger \& Herron (1985) menyatakan bahwa peserta 
didik harus mempelajari operasi matematika terlebih dahulu sebelum menyelesaikan soal-soal kimia. Dalam memahami materi pokok kesetimbangan kimia yang di dalamnya terdapat prinsip-prinsip operasi matematika peserta didik seharusnya menguasai operasi matematika dengan baik agar tidak terjadi kesalahan pemahaman yang berujung pada terjadinya miskonsepsi.

\section{c. Kategori Tidak Memahami}

Berdasarkan rekapitulasi rerata persentase tiap butir tes dalam IPMKK pada berbagai kategori tingkat pemahaman, maka dapat ditentukan soal yang memberikan kontribusi terbesar pada kategori tidak memahami, baik tidak memahami tipe TM-1 (jawaban inti tes dan alasan salah), tipe TM-2 (jawaban inti tes salah - alasan tidak diisi), atau tipe TM-3 (tidak menjawab inti tes dan alasan).

Tabel 4. Persentase Terbesar pada Kategori Tidak Memahami untuk Setiap Kabupaten dan Tingkat Provinsi DIY

\begin{tabular}{lcccccc}
\hline \multirow{2}{*}{ Tingkat } & \multicolumn{5}{c}{ Kategori Tidak Memahami Tipe } \\
\cline { 2 - 7 } & \multicolumn{2}{c}{ TM-1 } & \multicolumn{3}{c}{ TM-2 } & \multicolumn{2}{c}{ TM-3 } \\
\cline { 2 - 7 } & No Soal & $\%$ & No Soal & $\%$ & No Soal & $\%$ \\
\hline Provinsi DIY & 19 & 75,55 & 10 & 3,69 & 24 & 0,8 \\
Kota Yogyakarta & 19 & 73,15 & 19 & 9,72 & 23 & 1,39 \\
Bantul & 19 & 74,86 & 10 & 10,06 & 4,21 & 0,56 \\
Sleman & 23 & 84,74 & 5,10 & 2,63 & 2,24 & 0,53 \\
Kulon Progo & 19 & 81,25 & 1,21 & 1,92 & 2 & 1,44 \\
Gunung Kidul & 19 & 77,03 & 10 & 2,39 & 24 & 1,44 \\
\hline
\end{tabular}

Perlu diketahui meskipun tiap-tiap tipe dari kategori tidak memahami memiliki pola respon yang berbeda, bukan berarti ada tingkatan mana yang lebih baik, melainkan semua berada pada kondisi yang sama, yaitu peserta didik tidak memahami konsep yang ditanyakan pada soal tersebut. Namun demikian, peserta didik yang masuk dalam kategori tidak memahami tipe TM-3 perlu mendapatkan perhatian khusus, karena mereka adalah peserta didik jurusan IPA, yang berarti harus benar-benar menguasai konsep-konsep kimia secara benar dan menyeluruh. 


\section{d. Kategori Memahami}

Dengan mencermati hasil rekapitulasi persentase setiap butir tes dari setiap kabupaten dan provinsi dapat ditentukan butir tes yang memberikan kontribusi persentase terbesar pada kategori memahami, yaitu peserta didik yang menjawab inti tes dan alasan benar.

Tabel 5. Persentase Terbesar pada Kategori Memahami untuk Setiap Kabupaten dan Tingkat Provinsi DIY

\begin{tabular}{lcccc}
\hline \multirow{2}{*}{ Tingkat } & Total & \multicolumn{3}{c}{ Kategori Memahami } \\
\cline { 3 - 5 } & Sampel & No Soal & $\Sigma$ & $\%$ \\
\hline Provinsi DIY & 1002 & 2 & 706 & 70,46 \\
Kota Yogyakarta & 216 & 2 & 187 & 86,57 \\
Bantul & 179 & 2 & 156 & 87,15 \\
Sleman & 190 & 2 & 115 & 60,53 \\
Kulon Progo & 208 & 2 & 118 & 56,73 \\
Gunung Kidul & 209 & 4 & 130 & 62,20 \\
\hline
\end{tabular}

Soal nomor 4 yang menanyakan tentang contoh reaksi kesetimbangan heterogen dan cirinya menempati posisi pertama dalam hal persentase terbanyak peserta didik yang masuk pada kategori memahami untuk Kabupaten Kulon Progo, yaitu sebanyak 118 dari 208 (56,73\%) peserta didik. Soal nomor 4 juga menempati urutan kedua terbesar pada kategori memahami di tingkat Provinsi, Kota, Sleman, dan Gunung Kidul.

\section{e. Kategori Memahami Sebagian Tanpa Miskonsepsi}

Dengan mencermati hasil rekapitulasi persentase setiap butir tes dari setiap kabupaten dan provinsi dapat ditentukan butir tes yang memberikan kontribusi persentase terbesar pada kategori memahami sebagian tanpa miskonsepsi, yaitu peserta didik yang menjawab inti tes benar tetapi tidak mengisi alasan.

Kategori ini menunjukkan peserta didik dapat menjawab, tetapi mereka tidak dapat memberikan alasan atas jawaban yang dipilih. Kondisi yang demikian dikategorikan peserta didik memahami sebagian dari konsep yang ditanyakan tetapi ada bagian dari konsep tersebut yang belum 
sepenuhnya dipahami yang tidak termasuk miskonsepsi. Hal ini dapat disebabkan peserta didik belum tuntas dalam memahami konsep atau hanya menjawab spekulatif tanpa tahu alasannya.

Tabel 6. Persentase Terbesar pada Kategori Memahami Sebagian Tanpa

Miskonsepsi untuk Setiap Kabupaten dan Tingkat Provinsi DIY

\begin{tabular}{lcccc}
\hline \multirow{2}{*}{\multicolumn{1}{c}{ Tingkat }} & \multirow{2}{*}{$\begin{array}{c}\text { Total } \\
\text { Sampel }\end{array}$} & \multicolumn{3}{c}{$\begin{array}{c}\text { Kategori Memahami Sebagian } \\
\text { Tanpa Miskonsepsi }\end{array}$} \\
\cline { 3 - 5 } & & No Soal & $\Sigma$ & $\%$ \\
\hline Provinsi DIY & 1002 & 12 & 21 & 2,10 \\
Kota Yogyakarta & 216 & 12 & 18 & 8,33 \\
Bantul & 179 & 11 & 9 & 5,03 \\
Sleman & 190 & 10 & 6 & 3,16 \\
Kulon Progo & 208 & 4 & 3 & 1,44 \\
Gunung Kidul & 209 & 4,11 & 5 & 2,39 \\
\hline
\end{tabular}

Secara umum soal-soal yang masuk dalam persentase terbesar pada kategori ini berupa soal yang berisi konsep teoretis, hafalan $\left(\mathrm{C}_{1}\right)$, atau termasuk pada aspek pemahaman $\left(\mathrm{C}_{2}\right)$, seperti soal nomor 4 (kesetimbangan heterogen), 10 (pergeseran kesetimbangan karena perubahan konsentrasi), 11 (pergeseran kesetimbangan karena perubahan tekanan), dan 12 (peranan katalis dalam reaksi kesetimbangan).

Hasil penelitian Huddle \& Pillay (1996) menyimpulkan bahwa mayoritas mahasiswa di Witwatersrand Universitas belum memahami secara utuh konsep kesetimbangan kimia dengan kesulitan utama karena konsep ini dianggap abstrak. Lebih lanjut, dikemukakan bahwa contoh-contoh konkret penting untuk diberikan dalam memahaminya, karena contoh tersebut tidak mungkin diinterpretasikan salah oleh peserta didik.

\section{f. Kategori Miskonsepsi Peserta Didik dengan Alasan Terbuka}

IPMKK yang dikembangkan dalam penelitian ini memiliki perbedaan dengan instrumen pendeteksi miskonsepsi yang dikembangkan Amir dan Treagust, yaitu adanya tempat kosong yang memberikan kebebasan kepada peserta didik untuk mengemukakan alasannya sendiri di luar alasan yang telah tersedia. Dengan adanya tempat kosong diharapkan peserta didik 
yang ingin mengemukakan alasan dengan kalimatnya sendiri dapat tersalurkan dengan baik.

Berdasarkan data yang dikumpulkan menunjukkan ada sejumlah peserta didik yang menjawab alasan terbuka, yaitu sebanyak 714 orang. Setelah dianalisis dengan cara ditentukan benar salahnya, maka diperoleh pola jawaban yang mengandung $\mathrm{F}$ (option alasan kosong) pada berbagai kategori tingkat pemahaman yang ada. Adapun dari 714 peserta didik tersebut, sebanyak 237 orang berada pada kategori miskonsepsi tipe Mi-1.

\section{g. Umpan Balik Hasil Uji Coba Lapangan (Uji Fisibilitas)}

Setelah dilakukan uji coba lapangan (uji fisibilitas), maka untuk melihat mudah tidaknya IPMKK yang dihasilkan diterapkan oleh guru kimia SMA; dianalisis hasilnya; dan mendeteksi miskonsepsi kimia pada materi pokok kesetimbangan kimia, selain dilakukan wawancara, juga dilakukan pengumpulan data dengan menggunakan lembar angket keterlaksanaan sebagai umpan balik dari hasil uji coba lapangan (uji fisibilitas). Berdasarkan hasil pengisian angket menunjukkan bahwa sebanyak 30 guru (88,2\%) menyatakan IPMKK yang dikembangkan dapat diterapkan dengan mudah di lapangan, sedangkan 4 guru $(11,8 \%)$ menyatakan sulit diterapkan dengan alasan terutama pada ketidaksesuaian waktu yang disediakan dengan jumlah soal yang diberikan. Berdasarkan hal inilah, maka dalam revisi produk akhir dilakukan perubahan waktu yang disediakan untuk mengerjakan soal-soal dalam IPMKK.

Ditinjau dari mudah tidaknya menganalisis hasil penerapan IPMKK diketahui bahwa 34 guru (100\%) menyatakan mudah dengan catatan jika diberi contoh cara menganalisis data tersebut secara terperinci. Demikian juga dengan jawaban atas pertanyaan dapat tidaknya IPMKK mendeteksi terjadinya miskonsepsi pada peserta didik, ternyata seluruh guru yang diberi angket menjawab mudah. Hasil pengisian angket ini juga memberikan informasi bahwa sebanyak 28 guru $(82,4 \%)$ menyatakan hasil pendeteksian miskonsepsi dengan menggunakan instrumen ini sesuai dengan yang terjadi di lapangan.

Hasil pengisian angket juga menunjukkan bahwa sebagian guru tidak mengetahui adanya miskonsepsi pada konsep-konsep tertentu. Hal ini 
sesuai dengan pendapat Berg (1991: 17) yang menyatakan bahwa guru pada umumnya tidak mengetahui miskonsepsi yang sering dialami oleh peserta didiknya, karena ketika pembelajaran berlangsung guru seringkali serius dalam menyampaikan materi, sehingga perhatian terhadap peserta didiknya kurang.

\section{h. Revisi Produk}

Hasil uji fisibilitas sebagai uji coba terakhir terhadap Produk III IPMKK telah berhasil mendeteksi terjadinya miskonsepsi kimia pada materi pokok kesetimbangan kimia. Berdasarkan hasil wawancara dengan guruguru kimia SMA yang terlibat dalam uji fisibilitas, yaitu sebanyak 37 guru yang berasal dari 29 SMA (Negeri dan Swasta) diperoleh berbagai masukan yang berkaitan dengan produk IPMKK yang dikembangkan.

Masukan yang diperoleh terutama berkaitan dengan penerapan IPMKK, baik mengenai kejelasan kalimat dalam soal, kejelasan petunjuk penggunaan, cara menganalisis hasil tes maupun kecukupan alokasi waktu yang diperlukan untuk menyelesaikan tes. Semua masukan guru menjadi bahan akhir untuk merevisi dan menyempurnakan Produk III IPMKK agar menjadi produk akhir yang benar-benar mudah diterapkan oleh guru di lapangan dan hasilnya mudah dianalisis, sehingga membantu guru dalam mendeteksi terjadinya miskonsepsi, khususnya pada materi pokok kesetimbangan kimia.

Perbaikan lainnya berupa ketentuan waktu yang diperlukan untuk mengerjakan seluruh soal dalam IPMKK. Hasil uji fisibilitas diketahui bahwa alokasi waktu 2 jam pelajaran (90 menit) dirasakan oleh sebagian besar peserta didik belum memadai untuk menyelesaikan seluruh soal dalam IPMKK dengan baik. Selain itu dari umpan balik, sebanyak 13 dari 34 guru memberi masukan tentang alokasi waktu yang harus disesuaikan dengan banyaknya soal dan waktu ideal penyelesaian soal. Soal-soal IPMKK ini ditujukan terutama untuk mendeteksi terjadi tidaknya miskonsepsi pada peserta didik, sehingga sangat diperlukan waktu yang relatif memadai untuk mengerjakan soal dengan tenang dan baik.

Menurut Mardapi (2008: 92) pada umumnya waktu yang dibutuhkan untuk mengerjakan tes bentuk pilihan ganda adalah $2-3$ menit untuk 
setiap butir tes. Pendapat serupa dikemukakan oleh Sukardjo (2008: 90) yang menyatakan untuk ujian selama 90 menit jumlah butir tes pilihan ganda sekitar 25 - 30 soal, yang berarti setiap butir tes dikerjakan 3 - 3,6 menit. Pendapat lainnya dikemukakan oleh Utomo dan Ruijter (1994: 60), waktu 1,5-2,5 jam sebagai lama waktu terbaik seseorang untuk mengerjakan suatu ujian, karena lebih dari 2,5 jam akan dapat mengurangi keterandalan tes yang disebabkan ketahanan konsentrasi berpikir seseorang memiliki batas kemampuan. Berdasarkan berbagai kajian pustaka tersebut, maka ditetapkan waktu terbaik yang disediakan untuk mengerjakan IPMKK ini selama 150 menit (2,5 jam).

Pada akhirnya Produk Akhir IPMKK dikemas sedemikian rupa hingga menjadi produk akhir yang meliputi kata pengantar, sekilas tentang miskonsepsi, petunjuk penggunaan, kisi-kisi tes dalam IPMKK, instrumen berupa Tes Pilihan Ganda dengan Alasan Setengah-terbuka (TPGAST), kunci jawaban beserta pembahasan-nya, dan teknik analisis datanya.

\section{i. Kajian Produk Akhir}

Dalam penelitian ini digunakan analisis teori respon butir (TRB) untuk menentukan soal-soal yang fit atau valid setelah diujicobakan kepada 800 peserta didik. Dalam pengembangan tes diagnostik, analisis yang digunakan untuk validasi soal hanya bersifat mendukung pada pemilihan soal yang valid secara empiris, karena yang terpenting soal-soal tersebut benar-benar berfungsi sebagai instrumen untuk mendeteksi, dalam hal ini mendeteksi miskonsepsi yang terjadi pada peserta didik. Oleh karena itu, analisis menggunakan TRB dapat diganti dengan analisis teori klasik yang lebih mudah dan sederhana.

Berdasarkan hasil uji fisibilitas terhadap 1002 peserta didik yang berasal dari 29 SMA (Negeri dan Swasta) menunjukkan bahwa soal-soal yang terdapat dalam IPMKK telah berhasil mendeteksi adanya miskonsepsi pada peserta didik, baik miskonsepsi tipe Mi-1 maupun tipe Mi-2. Informasi ini sangat penting bagi guru dalam usahanya mendeteksi miskonsepsi yang terjadi pada anak didiknya, sehingga dengan segera dapat menyusun strategi pembelajaran yang tepat untuk mengatasinya. 
Sebanyak 714 peserta didik mengisi alasan di tempat kosong (option F), atau kalau dihitung ada sebesar 2,97\% (714 dari 24 x 1002 peserta didik). Jumlah tersebut memang relatif sedikit, namun merupakan awal yang menggembirakan bagi pengembangan suatu produk instrumen pendeteksi miskonsepsi yang dikembangkan, mengingat bentuk soal pendeteksi yang dikembangkan belum dikenal baik oleh peserta didik, sehingga sosialisasi kepada mereka.

Berdasarkan wawancara dan pengisian lembar angket umpan balik uji fisibilitas terhadap guru-guru yang terlibat dalam uji fisibilitas diperoleh informasi bahwa instrumen ini relatif mudah diterapkan tetapi perlu perubahan alokasi waktu, petunjuk penggunaan, dan teknik atau pedoman analisis data untuk mengetahui terjadi tidaknya miskonsepsi. Semua masukan dari hasil wawancara dan pengisian lembar angket ditindaklanjuti dalam bentuk revisi produk akhir yang nantinya dapat digunakan oleh guru-guru kimia SMA yang membutuhkan. Harapannya, Produk Akhir IPMKK ini benar-benar dapat membantu guru kimia SMA dalam mendeteksi miskonsepsi yang terjadi pada peserta didiknya dan dengan segera guru berusaha membantu mengatasinya melalui strategi pembelajaran yang tepat.

\section{Simpulan}

Berdasarkan hasil penelitian dapat disimpulkan sebagai berikut:

1. Telah berhasil dikembangkan Instrumen Pendeteksi Miskonsepsi Kesetimbangan Kimia (IPMKK) pada peserta didik kelas XI SMA yang berupa seperangkat instrumen Tes Pilihan Ganda dengan Alasan Setengah-Terbuka (TPG-AST) berjumlah 24 butir soal.

2. Berdasarkan expert judgment dalam FGD dihasilkan 30 butir soal yang diterima dengan perbaikan, sedangkan 10 butir soal dihilangkan dengan berbagai pertimbangan. Berdasarkan analisis menggunakan analisis teori respon butir (TRB) dengan tiga parameter diperoleh 24 butir soal yang fit dan 6 butir soal yang tidak fit.

3. Hasil uji fisibilitas menunjukkan bahwa guru-guru kimia SMA tidak mengalami kesulitan dalam menerapkan IPMKK dan menganalisisnya. 
Hasil analisis data yang berupa pola jawaban peserta didik menunjukkan bahwa IPMKK yang diterapkan di lapangan dapat mendeteksi terjadinya miskonsepsi kimia, yaitu miskonsepsi tipe Mi-1 sebesar 13,84\% dan tipe Mi-2 sebesar 18,43\% untuk tingkat Provinsi DIY.

\section{Daftar Pustaka}

Abraham, M. R, Grzybowski, E. B, Renner, J. W, et al. (1992). Understandings and misunderstandings of eighth graders of five chemistry concepts found in textbooks. Journal of Research in Science Teaching, 29(2), 105-120.

Amir, Frankl, \& Tamir. (1987). Justifications of answers to multiple choice items as a means for identifying misconceptions. In Proceedings of the Second International Seminar on Misconceptions and Educational Strategies in Science and Mathematics. Vol I. 15-25. Ithaca, New York: Cornell University.

Berg, E., van den. (1991). Miskonsepsi fisika dan remidiasi. Salatiga: Universitas Satya Wacana.

Borg, W. R.\& Gall, M. D. (1983). Educational research: An introduction, Fourth edition. New York : Longman, Inc.

Dierks, W, Weninger, J. \& Herron, J. D. (1985). Mathematics in the chemistry classroom: Part 1 . The special nature of quantity equations. Journal of Chemical Education, 62(10), 839-841.

Ditjen Dikti. (2008). Permendiknas No. 20/2008 tentang Standar Penilaian. Jakarta: Depdiknas.

Gabel, D. (1999). Improving teaching and learning through chemistry education research: A look to the future. Journal of Chemical Education, 76(4), 548-554.

Hambleton, R. K. \& Swaminathan, H. (1985). Item response theory. Boston, MA: Kluwer Nijhoff Publishing. 
Herron, J. D. \& Greenbowe, T. J. (1986). What can we do about Sue: A case study of competence. Journal of Chemical Education, 63(6), 528531.

Huddle, P. A. \& Pillay, A. E. (1996). An in-depth study of misconceptions in stoichiometry and chemical equilibrium at a South African University. Journal of Research in Science Education, 33(1), 65-67.

Krishnan, Shanti R, \& Howe, Ann C. (1994). The mole concept: Developing in instrument to assess conceptual understanding. Journal of Chemical Education, 71(8), 653-655.

Mardapi, Djemari (2008). Teknik penyusunan instrumen tes dan nontes. Yogyakarta: Mitra Cendikia Yogyakarta Press.

Nakhleh, M. B. (1992). Why some students don't learn chemistry: Chemical misconceptions. Journal of Chemical Education, 69(3), 191.

Sukardjo. (2008). Penilaian hasil belajar kimia. Diktat. Yogyakarta: FMIPA $-\mathrm{UNY}$.

Sutiman., Salirawati, Das, \& Permanasari, Lis. (2003). Identifikasi miskonsepsi konsep-konsep kimia SMA di Kabupaten Sleman. Laporan Penelitian. Yogyakarta: Lembaga Penelitian UNY.

Suparno, Paul. (2005). Miskonsepsi \& perubaban konsep pendidikan fisika. Jakarta: Grasindo.

Treagust, D. (1987). An approach for helping students and teachers diagnose misconceptions in specific science content area. In Proceedings of the Second International Seminar on Misconceptions and Educational Strategies in Science and Mathematics. Vol II. 519-520. Ithaca, New York: Cornell University.

Utomo, Tjipto \& Ruijter, Kees. (1994). Peningkatan dan pengembangan pendidikan. Jakarta: Gramedia Pustaka Utama. 